Jurnal Care Vol .5, No2,Tahun 2017

\title{
STUDI FENOMENOLOGI: TINDAKAN ANAK PEREMPUAN DALAM PENERIMAAN TERHADAP IBU DENGAN KANKER PAYUDARA DI RS TK.II DR. SOEPRAOEN
}

\author{
Sirli Mardianna Trishinta ${ }^{1}$, Retty Ratnawati ${ }^{2}$, Septi Dewi Rachmawati ${ }^{3}$ \\ 1) Mahasiswa Magister Keperawatan Fakultas Kedokteran Universitas Brawijaya \\ Peminatan Keperawatan Jiwa \\ $\left.{ }^{2,3}\right)$ Dosen Magister Keperawatan Fakultas Kedokteran Universitas Brawijaya \\ e-mail :sirli.shinta@yahoo.com
}

\begin{abstract}
Family problems that resulted in acceptance of daughter against family members with breast cancer is important to be studied. This is because the variance of acceptance experience must be appropriate. Therefore, experience in family members identify by qualitative phenomenological research on daughter acceptance in RS Tk. II dr. Soepraoen. This study aims to realize the meaning experience acts from daughter in acceptance mothers with breast cancer. This study was conducted to eight participants which selected according to the inclusion criteria of this study: (1) a daughter from patients with breast cancer, (2) age 20 to 40 years (3) living single-roof with patients, (4) last education in high school, (5) Caring for patients with diagnosed breast cancer at least 2 months, (6) breast cancer suffered by patients at least stage 2, (7) patients undergoing medical treatment, (8) bealthy participants, without complication and physical illness history, (9) accept to become an participant. Research conducted for 1 month. Data were collected by indepth interviews with the help of interview guides, recorders, and field notes. In this study used qualitative data analysis of verbatim transcripts using Braun \& Clarke. The result from analysis there is a theme of giving maximum effort to cure the mother. This study shows the acts of daughter to acceptance mothers with breast cancer by giving the maximum effort to cure the mother.
\end{abstract}

Keywords: acceptance, breast cancer, daughter, mother

\begin{abstract}
ABSTRAK
Permasalahan keluarga yang ditimbulkan dalam penerimaan anak perempuan terhadap anggota keluarga dengan kanker payudara penting diteliti. Bagaimanapun pengalaman penerimaan yang beragam dan ini memerlukan pembuktian apakah penerimaan tersebut sudah tepat. Penelitian ini bertujuan untuk mengeksplorasi makna pengalaman tindakan anak perempuan dalam penerimaan terhadap ibu dengan kanker payudara di RS Tk II dr. Soepraoen. Penelitian ini dilakukan pada delapan partisipan dipilih sesuai kriteria inklusi penelitian yaitu: (1) anak perempuan pasien dengan kanker payudara, (2) usia 20 sampai 40 tahun (3) tinggal satu atap dengan pasien, (4) pendidikan terakhir SMA, (5) merawat pasien dengan terdiagnosa kanker payudara minimal 2 bulan terakhir, (6) kanker payudara yang
\end{abstract}


diderita pasien minimal stadium 2, (7) pasien yang dirawat menjalani perawatan secara medis, (8) partisipan sehat, ditandai dengan tidak adanya keluhan fisik dan tidak mempunyai riwayat penyakit fisik, (9) bersedia menjadi partisipan. Penelitian dilakukan selama 1 bulan. Pengambilan data dilakukan dengan indepth interview dengan bantuan pedoman wawancara, recorder, dan field note. Pada penelitian ini digunakan analisis data kualitatif dari transkrip verbatim menggunakan Braun \& Clarke. Pada analisa didapatkan tema memberikan upaya yang maksimal untuk kesembuhan ibu. Kesimpulan penelitian ini menunjukkan tindakan penerimaan dilakukan anak perempuan terhadap ibu dengan kanker payudara dengan memberikan upaya maksimal untuk kesembuhan ibu.

Kata Kunci: anak perempuan, ibu, kanker payudara, penerimaan.

\section{PENDAHULUAN}

Kanker payudara termasuk penyebab kematian tertinggi di dunia (Saragih, 2012). Menurut data GLOBOCAN (IARC) tahun 2012 diketahui bahwa kanker payudara merupakan penyakit kanker dengan persentase kasus baru tertinggi, yaitu sebesar 43,3\%, dan persentase kematian akibat kanker payudara sebesar 12,9\%. Provinsi Jawa Timur merupakan provinsi dengan estimasi penderita kanker terbanyak, yaitu sekitar 61.230 orang (Infodatin, 2015). Berdasarkan studi pendahuluan peneliti di ruang kemoterapi RS dr. Soepraoen Malang, prevalensi kanker terbanyak adalah kanker payudara sebesar 88\%.

Perjalanan klinis kanker, yang dapat mencakup diagnosis awal, pengobatan, rehabilitasi, dan kesintasan baik berupa remisi atau kesembuhan, kekambuhan, terjadi dalam akhir kehidupan pasien kanker. Penelitian yang berkaitan dengan kanker payudara selama ini kebanyakan berfokus pada penerimaan pasien. Seperti penelitian Reed et al (2016) bahwa penerimaan emosional pasien ditunjukkan mengikuti proses gejala penyakit pada pasien kanker payudara dari waktu ke waktu mengikuti diagnosis dan pengobatan (Reed et al., 2016).

Perubahan yang terjadi pada anggota keluarga ini dapat membuat keluarga berkembang pada perubahan fisik dan emosional. Hal ini disebabkan karena pengalaman yang berat, penuh rasa sakit dan keputusasaan. Perubahan aspek kesejahteraan psikologis keluarga kemudian mempengaruhi keluarga dalam memberikan perawatan yang kompleks pada pasien kanker di rumah. Padahal kedekatan individu dalam keluarga dapat meningkatkan kualitas hidup pasien dengan kanker (Saragih, 2012). 
Jurnal Care Vol .5, No2,Tahun 2017

Cheng Li et al, (2016) menyatakan bahwa mayoritas pasien kanker yang tidak tahu dan bingung menangani kanker payudara yang dialami tetap bersedia menerima konseling dan pengujian jika keluarga mereka turut berpartisipasi (Cheng et al., 2016). Hal ini menunjukkan bahwa keberhasilan pasien melalui fase perubahan akibat kanker payudara memiliki dampak yang berbeda tergantung pada keberadaan keluarga dalam perannya yang tidak bisa dilepaskan pada kehidupan pasien seperti pemberian dukungan pada keluarga lain, kedekatan secara lokasi geografis, serta pola-pola keluarga dalam mengatasi masalah sebelumnya (Marshall, 2010).

Dukungan keluarga adalah sikap, tindakan dan penerimaan keluarga terhadap penderita yang sakit (Siburian and Wahyuni, 2012). Sedangkan penerimaan adalah tahapan seseorang menerima kenyataan bahwa salah satu yang dicintai secara fisik sudah pergi atau hilang, serta mengakui bahwa realitas baru yang dialaminya adalah realitas permanen. Namun proses ini akan terus berulang setiap kali individu mengalami perubahan berupa kehilangan (KüblerRoss and Kessler, 2014).
Peran perawat dalam mendukung penerimaan keluarga pada anggota keluarga yang sedang berada pada situasi stress seperti diagnosis dari penyakit yang mengancam jiwa diperlukan untuk meningkatkan kualitas dan keadamaian akhir hidup pasien tersebut. Keluarga terdekat pasien kanker payudara, yaitu suami dan anak akan mempengaruhi hasil pada pasien kanker payudara (Siburian and Wahyuni, 2012).

Perawat dalam perannya sebagai care giver juga diperlukan dalam menekankan aspek lain untuk mencegah internalisasi negatif akibat label penerimaan dan penolakan yang diberikan (Rydlo, 2010). Diperlukan penekanan pada bentuk lain seperti pemberian empati dengan cara melihat situasi dari sudut pandang orang tersebut. Kemudian perawat baru dapat menyimpulkan bahwa tanggapan yang beragam tentang penyakit dilihat dari segi pengalamannya melalui perubahan, sehingga penyesuaian tidak secara langsung dipahami sebagai proses dalam suatu tahapan (Telford et al., 2006).

Pada studi pendahuluan yang dilakukan di RS Tk. II dr. Soepraoen Malang pada salah satu anak perempuan pasien kanker payudara didapatkan gambaran bahwa 
Jurnal Care Vol .5, No2,Tahun 2017

pengalaman penerimaan keluarga

mengalami ketidakberdayaan dan menyangkut proses emosi yang selalu berubah. Anak mengalami kesedihan dan ketakutan akan kehilangan yang mungkin dihadapi. Anak juga semakin ketakutan jika terbayang perubahan sikap ayahnya terhadap ibunya. Saat melihat ayahnya merasa sedih, bingung, ketakutan dengan kondisi yang menimpa istri, dan mulai membayangkan jika harus menghadapi kematian pasangan dalam waktu singkat. Sikap ayah yang siap dengan kehilangan dan bersiap mencari pengganti membuat anak mengalami kesedihan. Padahal perasaan sedih dan takut yang dialami anak tersebut harus segera dilalui supaya bisa segera menerima dan mendukung ibunya. Walaupun bentuk dukungan seperti merawat ibu atau mengganti peran ibu dalam mengurus rumah tangga diakui juga menjadi beban tersendiri terutama bagi anak perempuan.

Saat anak perempuan melakukan perawatan saat ibu di rawat di rumah sakit, anak tampak kelelahan dan frustasi dengan keadaannya. Saat melalukan pengamatan secara acak di ruang rawat inap bedah wanita di RS Tk. II $\mathrm{dr}$. Soepraoen Malang, peneliti melihat bahwa 5 dari 5 anak perempuan yang merawat ibu dengan kanker payudara keputusasaan dengan keadaan yang dialaminya. Padahal ketidakberdayaan dan keputusasaan ini jika tidak ditangani dapat menjadi depresi pada anak perempuan.Sumner, et al (2015) melaporkan anak perempuan yang merawat ibu dengan kanker mengalami adaptasi koping aktif, perilaku pembiaran, perencanaan kebutuhan secara terus menerus, dan perilaku menyalahkan diri sendiri, serta mengalami kesulitan dalam perawatan. Namun keberadaan anak perempuan memberikan dukungan emosional dan dukungan nyata dari segi spiritualitas (misalnya perdamaian, makna, iman) dalam merawat ibu dengan kanker payudara. Meskipun peserta dalam penelitian tersebut tidak menunjukkan tingkat klinis distress emosional yang signifikan, hampir $25 \%$ dari sampel masyarakat dan 10\% dari sampel klinik memiliki gejala depresi klinis yang signifikan. Penelitian tersebut menggarisbawahi kebutuhan untuk intervensi disesuaikan perawat untuk mempertimbangkan karakteristik psikososial yang unik pada anak perempuan yang merawat ibu dengan kanker payudara. 
Dalam melaksanakan adaptasi dari perubahan yang terjadi dalam keluarga tersebut, proses penerimaan anak perempuan terus berubah dalam menghadapi perubahan kondisi pasien kanker payudara yang tidak menentu.Tahapan penerimaan yang ditempuh beragam, mulai menolak hingga menerima. Dalam proses penerimaan terdapat dua kemungkinan sikap yang dimunculkan dimunculkan oleh anggota keluarga terhadap individu yang didiagnosis kanker payudara, yaitu menerima atau menolak.

Secara normatif, sebagian besar orang tentunya menyatakan telah menerima keberadaan pasien, karena bagaimanapun mereka menjadi bagian dari keluarga. Namun pada kenyataannya, respon "penerimaan" masing-masing individu tidak selalu sama. Respon yang sebenarnya ini akan menjelaskan apakah mereka telah benar-benar menerima atau sebenarnya melakukan penolakan dengan cara-cara dan perlakuan tertentu. Hal ini juga akan menjelaskan tentang bagaimana pola sebuah keluarga untuk dapat menyesuaikan diri dengan keberadaan individu yang berbeda tersebut (Hendriani et al., 2006)
Pada kenyataannya anak berfokus pada aspek untuk menggunakan pengalaman masa lalunya yang bisa digunakan pada tahapannya melakukan penyesuaian pada kondisi yang sedang dialami. Keluarga dengan anggota keluarga terdiagnosa kanker dipastikan mengalami pengalaman yang sangat melelahkan, serta melakukan pengorbanan dari berbagai aspek hidup (Klassen et al., 2011). Kelelahan yang dirasakan menjadi lebih besar jika menghadapi jika anggota keluarga yang terdiagnosis kanker mengalami komplikasi sementara pengobatan yang dijalaninya tidak dapat dimodifikasi. Keadaan ini semakin menuntut keluarga untuk siap menghadapi keadaan pasien mulai dari awal penyakit terdiagnosa sampai akhirnya mampu menerima ancaman kehilangan, kerugian, frustrasi dan perubahan pada dirinya dan keluarga secara keseluruhan (Barakat et al., 2010).Padahal penerimaan dari setiap anggota keluarga terutama anak perempuan, akan memberikan "energi" dan kepercayaan dalam diri individu untuk lebih berusaha meningkatkan setiap kemampuan yang dimiliki, sehingga hal ini akan membantunya untuk dapat hidup mandiri, lepas dari ketergantungan pada bantuan orang lain. Sebaliknya, penolakan yang diterima dari orang-orang terdekat 
dalam keluarganya akan membuat individu semakin rendah diri dan menarik diri dari lingkungan, selalu diliputi oleh ketakutan ketika berhadapan dengan orang lain maupun untuk melakukan sesuatu, sehingga pada akhirnya mereka benar-benar menjadi orang yang tidak dapat berfungsi secara sosial serta tergantung pada orang lain, termasuk dalam merawat diri sendiri (Hendriani et al., 2006, Sumner et al., 2015).

Adanya permasalahan keluarga yang ditimbulkan dalam penerimaan anak perempuan terhadap anggota keluarga dengan kanker payudara penting diteliti. Hal ini karena bagaimanapun pengalaman penerimaan yang beragam dan perlu dibuktikan apakah penerimaan tersebut sudah tepat. Oleh karena itu dilakukan penelitian qualitative phenomenology tentang tindakan anak perempuan dalam penerimaan yang menghadapi pengalaman ibu dengan kanker payudara di RS Tk II dr. Soepraoen. Tujuan dari penelitian ini adalah untuk mengeksplorasi makna pengalaman penerimaan anak perempuan terhadap ibu dengan kanker payudara.

\section{METODE PENELITIAN}

Penelitian ini menggunakan pendekatan fenomenologi. Partisipan penelitian adalah 8 anak perempuan yang dipilih sesuai dengan kriteria inklusi penelitian, yang direkrut berdasarkan data penanggung jawab pasien di RS TK. II dr. Soepraoen Kota Malang. Partisipan dalam penelitian ini dipilih sesuai kriteria inklusi penelitian yaitu: (1) anak perempuan pasien dengan kanker payudara, (2) usia 20 sampai 40 tahun (3) tinggal satu atap dengan pasien, pendidikan terakhir SMA, (5) merawat pasien dengan terdiagnosa kanker payudara minimal 2 bulan terakhir, (6) kanker payudara yang diderita pasien minimal stadium 2, $\quad$ (7) pasien yang dirawat menjalani perawatan secara medis, (8) partisipan sehat, ditandai dengan tidak adanya keluhan fisik dan tidak mempunyai riwayat penyakit fisik, (9) bersedia menjadi partisipan. Penelitian dilakukan pada Mei 2017 di ruang perawat ruang kemoterapi RS TK. II dr. Soepraoen Kota Malang yang terdapat pasien dengan diagnosa kanker payudara. Dalam penelitian kualitatif, instrumen utama dalam mengumpulkan data adalah peneliti sendiri. Terdapat ketentuan agar peneliti mampu menjadi instrumen penelitian yang baik yaitu memiliki 
kemampuan metode kualitatif, melaksanakan prosedur etika penelitan dengan memenuhi prinsip-prinsip etik, serta memahami ilmu pengetahuan tentang masalah psikososial pada keluarga. Peneliti mengembangkan pertanyaan dalam pedoman wawancara mengenai penerimaan keluarga terhadap anggota keluarga yang terdiagnosa kanker payudara. Pengembangan pertanyaan ini sangat berpengaruh pada kemampuan peneliti untuk mengeksplorasi pengalaman partisipan dan kemampuan peneliti dalam memposisikan diri sebagai pendengar yang baik. Selain itu peneliti juga dibantu oleh recorder dan field note. Alat perekam suara berfungsi untuk merekam percakapan verbal yang terjadi selama proses wawancara. Alat perekam yang dipakai adalah perekam suara/ recorder smartphone. Penggunaan lembar catatan membantu peneliti untuk melengkapi data pada saat melakukan analisis.

Analisis data dilakukan dengan analisis data menggunakan Braun \& Clarke (2006) yang dijelaskan oleh Braun \& Clarke (2013), yaitu: 1) Familiarisation with the data, 2) Coding (Koding), 3) Searching for themes (Mencari Tema), 4) Reviewing themes (Mereview Tema), 5) Defining and naming themes (Memberikan penjelasan dan memberikan nama pada tema), 6) Writing up (Menulis Ulang). Pengecekan keabsahan data dapat dilakukan dengan menggunakan Lincoln dan Guba (1985). Menurut perspektifnya, validasi menurut Lincoln dan Guba (1985) merupakan metode yang penggunaan istilah alternatifnya lebih banyak berlaku pada aksioma naturalistic. Validisi ini terdiri dari 4 buah yaitu transferability, dependability, Confirmability, dan Credibility.

\section{HASIL}

Peneliti menggunakan istilah "P" sebagai pengganti partisipan dalam menyampaikan pernyataan hasil wawancara.

Tabel 1 menggambarkan tentang data demografi partisipan yaitu rentang usia, pendidikan, pekerjaan, status perkawinan, lama merawat ibu, stadium kanker payudara, dan jenis pengobatan yang sudah dialami ibu. Berdasarkan tabel tersebut diketahui bahwa rentang usia 26 - 30 tahun merupakan rentang usia terbanyak partisipan yang merawat ibu dengan kanker payudara. Selain itu dapat dilihat juga rata-rata pendidikan partisipan adalah SMA. 
Jurnal Care Vol .5, No2,Tahun 2017

Tabel 1. Data Demografi Partisipan

\begin{tabular}{cccc}
\hline & Data Demografi & Partisipan & $\begin{array}{c}\text { Total } \\
\text { partisipan }\end{array}$ \\
\hline Usia & $20-25$ & P7, P8 & 2 \\
& $26-30$ & P1, P2, P4, P5, P6 & 5 \\
& $30-35$ & - & 0 \\
Pendidikan & $36-40$ & P3 & 1 \\
& SMA & P2, P3, P4, P5, P6 & 5 \\
Pekerjaan & Pendidikan tinggi & P1, P7, P8 & 3 \\
& Tidak bekerja & P4, P8 & 2 \\
& Ibu rumah tangga & P2, P5, P6 & 3 \\
& Wiraswasta & P3 & 1 \\
Status & Karyawan & P1, P7 & 2 \\
perkawinan & Belum kawin & P1, P3, P4, P7, P8 & 5 \\
\hline
\end{tabular}

Tabel 2 Status Kondisi Kanker Payudara

\begin{tabular}{llll}
\hline Lama & $3-6$ bulan & P1, P2 & 2 \\
perawatan & 6-12bulan & P5, P6, P7, P8 & 4 \\
payudara & $>12$ bulan & P3 & 1 \\
\hline Stadium kanker & Stadium 2 & P1, P3, P8 & 3 \\
payudara & Stadium 3 & P6, P7 & 2 \\
& Stadium 4 & P2, P4, P5 & 3 \\
\hline Jenis & Kemoterapi & P5 & 1 \\
penatalaksanaan & Kemoterapi dan Operasi & P1, P2, P3, P4, P6, P7, P8 & 7 \\
\hline Jenis & Medis saja & P1, P3, P6, P7, P8 & 5 \\
pengobatan & Medis dan alternatif & P2, P4, P5 & 3 \\
\hline
\end{tabular}

Sebagian besar partisipan juga merawat ibu dengan kanker payudara dalam rentang waktu antara 6-12 bulan terlihat pada tabel 2. Sedangkan paling lama partisipan merawat ibu yaitu 18 bulan. Partisipan ini dimasukkan ke dalam kategori $>12$ bulan, yaitu partisipan 3 . Selanjutnya, seluruh partisipan dilakukan kemoterapi, dengan 1 pasien yang hanya dilakukan kemoterapi saja belum dioperasi. Demografi yang terakhir yaitu jenis pengobatan yang sudah dilakukan. Berdasarkan data tersebut diketahui bahwa paling banyak partisipan yang memiliki ibu dengan kanker payudara stadium 2 dan 3 melakukan pengobatan medis saja, sedangkan ibu kanker payudara stadium 4 melakukan 
pengobatan alternatif sebelum melakukan pengobatan medis. Pengobatan alternatif yang dimaksud adalah pengobatan non medis.

Tema: Memberikan Upaya Yang Maksimal Untuk Kesembuhan Ibu

Tema yang diperoleh dari sub tema dan kategori pada tujuan mengeksplorasi tindakan partisipan selama proses penerimaan terhadap ibu dengan kanker payudara adalah memberikan upaya yang maksimal untuk kesembuhan ibu. Memberikan berarti menyerahkan sesuatu. Upaya merupakan bentuk usaha atau ikhtiar. Keras berarti kegigihan dan kesungguhan hati. Sembuh berarti sehat kembali. Arti tema ini adalah menyerahkan segala sesuatu dengan mengusahakan secara gigih dan sungguhsungguh dengan tujuan ibu menjadi sehat kembali. Bentuk usaha yang dilakukan partisipan dalam tema ini menunjukkan tindakan penerimaan dengan cara yang positif dalam menghadapi ibu dengan kanker payudara. Tema dua ini menjawab tujuan khusus dua yaitu mengeksplorasi tindakan partisipan selama proses penerimaan terhadap ibu dengan kanker payudara.
Sub Tema 1: Memberikan Bakti Anak terhadap Ibu

Kategori mencari pengobatan untuk ibu dinyatakan oleh partisipan dengan menjelaskan bahwa anak perempuan melakukan usaha mencari pengobatan untuk ibu dengan kanker payudara. Hal ini diungkapkan oleh partisipan sebagai berikut:

"Ya menerima dengan berusaha cari pengobatan ... usaha mengobati ibuk" (Partisipan 1, Partisipan 2).

Kategori merawat ibu dinyatakan oleh partisipan dengan menjelaskan bahwa anak perempuan melakukan usaha merawat ibu dengan kanker payudara. Hal ini diungkapkan oleh partisipan sebagai berikut:

"berpikirnya ... berbakti pada orang tua, terus mumpung ibu masib ada, dirawat sepenubnya" (Partisipan 1, Partisipan 2).

"Ya... orangtua.. dieman eman" (Partisipan 3).

Kategori mencari pengobatan untuk ibu dan merawat ibu di atas tergabung menjadi sub tema memberikan bakti anak terhadap ibu. Sebuah bentuk balas budi dari anak terhadap ibu dengan berbakti pada ibu. 
Jurnal Care Vol .5, No2,Tahun 2017

\begin{tabular}{|l|l|l|}
\hline Kategori & Tema & Tujuan Khusus \\
\hline
\end{tabular}

\begin{tabular}{|c|}
\hline $\begin{array}{c}\text { Mencari pengobatan } \\
\text { untuk ibu }\end{array}$ \\
\hline Merawat ibu
\end{tabular}

\begin{tabular}{|c|c|c|c|}
\hline Memberikan & Menemani ibu & \multirow{3}{*}{$\begin{array}{l}\text { Memberikan upaya } \\
\text { yang maksimal } \\
\text { untuk kesembuhan }\end{array}$} & \multirow{3}{*}{$\begin{array}{l}\text { Mengeksplorasi } \\
\text { tindakan partisipan } \\
\text { selama proses } \\
\text { penerimaan } \\
\text { terhadap ibu dengan } \\
\text { kanker payudara }\end{array}$} \\
\hline $\begin{array}{l}\text { perhatian terhadap } \\
\text { penyakit ibu }\end{array}$ & $\begin{array}{c}\text { dalam melalui sakit } \\
\text { yang dialami }\end{array}$ & & \\
\hline Berusaha tetap kuat & $\begin{array}{l}\text { Memperjuangkan } \\
\text { untuk tetap tegar }\end{array}$ & & \\
\hline
\end{tabular}

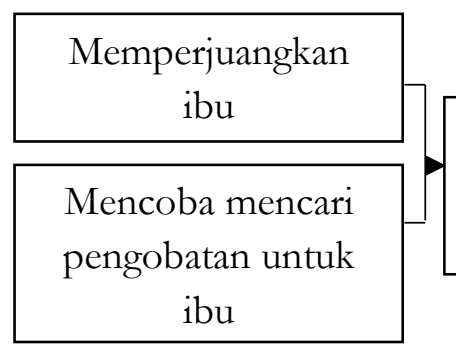

Memposisikan diri sebagai pendukung ibu

Bagan 1. Proses Analisa Tema

Sub Tema 2: Menemani Ibu dalam melalui Sakit yang Dialami

Kategori memberikan perhatian terhadap penyakit ibu dinyatakan oleh partisipan dengan menjelaskan bahwa anak perempuan memberikan perhatian terhadap ibu dengan kanker payudara. Hal ini diungkapkan oleh partisipan sebagai berikut: "saya memang saya sengaja niat merawat ibuk." (Partisipan 2).

"mengurus ibuk dulu, nanti kalau sudah bisa ngapa-ngapain, kalau sudah bisa ditinggal, kalau sekarang kan masih belum bisa ditinggal, tidak bisa ngapa-ngapain" (Partisipan 2).

Kategori memberikan perhatian terhadap penyakit ibu merupakan sub tema dari menemani ibu dalam melalui sakit yang dialami. Merupakan bentuk memberikan dukungan dengan menemani ibu dengan 
memberikan perhatian terhadap ibu dalam melalui sakit yang dialami.

Sub Tema 3: Memperjuangkan untuk Tetap Tegar

Kategori berusaha tetap kuat dinyatakan oleh partisipan dengan menjelaskan bahwa anak perempuan memberikan berusaha tetap kuat menghadapi ibu dengan kanker payudara. Hal ini diungkapkan oleh partisipan sebagai berikut:

"yawes sabar, namanya juga cobaan" (Partisipan 1, Partisipan 2, Partisipan 5).

"Saya barus kuat supaya bisa mendukung ibu" (Partisipan 1, Partisipan 3)

"Walaupun saya menangis dan sedih saya harus kuat" (Partisipan 5, Partisipan 6,Partisipan 7) Kategori berusaha tetap kuat merupakan sub tema dari memperjuangkan untuk tetap tegar sebagai bentuk usaha dan perjuangan yang terus menerus untuk tetap mampu menghadapi keadaan yang dialami.

Sub Tema 4: Memposisikan Diri sebagai

Pendukung Ibu

Kategori memperjuangkan ibu dinyatakan oleh partisipan dengan menjelaskan bahwa anak perempuan berusaha memberikanyang terbaik untuk ibu dengan kanker payudara. Hal ini diungkapkan oleh partisipan sebagai berikut:

"jadi salah satu harus berkorban, jadi aku sing ngalab" (Partisipan 2).

"pasrah, yang sembuh yang mengalab" (Partisipan 2; Partisipan 5)

"Sabar. Ya harus sabar, ibunya minta apa-apa ya dituruti, pokoknya lebih sabar, gak berani marah-marah atau mbentak. Ibunya pingin apa, disurub apa mesti langsung take kerjain" (Partisipan 2, Partisipan 4)

Kategori memperjuangkan ibu merupakan sub tema dari memposisikan diri sebagai pendukung ibu. Anak perempuan membuat dirinya sebagai pendukung ibu dengan terus memperjuangkan memenuhi kebutuhan ibu.

\section{PEMBAHASAN}

Memberikan berarti menyerahkan sesuatu. Upaya merupakan bentuk usaha atau ikhtiar. Keras berarti kegigihan dan kesungguhan hati. Sembuh berarti sehat kembali. Arti tema penelitian ini adalah menyerahkan segala sesuatu dengan mengusahakan secara gigih dan sungguhsungguh dengan tujuan ibu menjadi sehat kembali. Bentuk usaha yang dilakukan partisipan dalam tema ini menunjukkan tindakan penerimaan dengan cara yang 
positif dalam menghadapi ibu dengan kanker payudara.Seseorang yang mengalami kehilangan tidak akan pernah menyukai kenyataan ini atau membuatnya baik-baik saja, tapi akhirnya menerimanya. Seseorang mulai belajar untuk hidup bersama kehilangannya. Ini adalah norma baru yang harus dipelajari untuk melanjutkan hidup. Seseorang yang mengalami kehilangan harus mencoba hidup sekarang di dunia di mana sesuatu yang dicintai hilang (Kübler-Ross and Kessler, 2014).

Dalam melawan norma baru ini, pada awalnya banyak yang ingin mempertahankan kehidupan sama seperti sebelum mengalami kehilangan. Pada waktunya, melalui potongan-potongan penerimaan, bagaimanapun seseorang tidak dapat mempertahankan masa lalu secara utuh. Keadaan telah berubah selamanya dan harus menyesuaikan diri kembali. Seseorang harus belajar menata ulang peran, menugaskannya kembali ke orang lain atau membawanya ke diri sendiri (Kübler-Ross and Kessler, 2014).

Menemukan penerimaan mungkin hanya mengalami hari-hari yang lebih baik daripada hari-hari buruk. Saat seseorang mulai hidup kembali dan menikmati hidup, sering merasa bahwa dengan berbuat demikian, dapat mengkhianati orang yang kita cintai. Padahal seseorang tidak pernah bisa menggantikan apa yang telah hilang, tapi kita bisa membuat koneksi baru, hubungan baru yang bermakna, inter dependensi baru. Daripada menyangkal perasaan, seseorang perlu mendengarkan kebutuhannya; menyadari bahwa semua tetap bergerak, berubah, tumbuh, dan berevolusi. Seseorang mulai hidup lagi, tapi tidak bisa melakukannya sampai telah memberikan kesedihan pada waktunya (Kübler-Ross and Kessler, 2014).

Kesulitan menerima keadaan, kondisi mental yang jatuh, dan kebimbangan yang terus dirasakan membuat perasaan yang bercampur pada diri anak perempuan. Anak perempuan mengalami pertentangan perasaan penerimaan dengan semua kondisi yang dihadapi tersebut di dalam dirinya. Namun demikian, anak perempuan tetap memberikan upaya untuk kesembuhan ibu. Upaya yang melibatkan perasaan anak perempuan tersebut menjadi upaya yang keras bagi anak perempuan. Upaya 
yang keras tersebut tetap dilakukan karena kasih sayang yang ingin diberikan anak perempuan kepada ibu yang menderita kanker payudara.

\section{KESIMPULAN}

1. Tema yang diperoleh dari sub tema dan kategori pada tujuan mengeksplorasi tindakan partisipan selama proses penerimaan terhadap ibu dengan kanker payudara adalah memberikan upaya yang maksimal untuk kesembuhan ibu.

2. Sub tema dari tema memberikan upaya yang maksimal untuk kesembuhan ibu antara lain memberikan bakti anak terhadap ibu, menemani ibu dalam melalui sakit yang dialami, memperjuangkan untuk tetap tegar, memposisikan diri sebagai pendukung ibu.

3. Kategori mencari pengobatan untuk ibu dan merawat ibu di atas tergabung menjadi sub tema memberikan bakti anak terhadap ibu.

4. Kategori memberikan perhatian terhadap penyakit ibu merupakan sub tema dari menemani ibu dalam melalui sakit yang dialami.

5. Kategori berusaha tetap kuat merupakan sub tema dari memperjuangkan untuk tetap tegar sebagai bentuk usaha dan perjuangan yang terus menerus untuk tetap mampu menghadapi keadaan yang dialami.

6. Kategori memperjuangkan ibu merupakan sub tema dari memposisikan diri sebagai pendukung ibu. Anak perempuan membuat dirinya sebagai pendukung ibu dengan terus memperjuangkan memenuhi kebutuhan ibu.

\section{SARAN}

Ibu menghadapi tantangan untuk mengatasi kanker dan penyakitnya. Ibu mungkin butuh bantuan untuk diperhatikan namun juga anak perlu diberikan dukungan secara informasi maupun untuk menguatkan penerimaannya. Staf di rumah sakit dan perawatan primer juga ada baiknya ditempatkan untuk membantu mendukung supaya tindakan anak perempuan dalam penerimaan terhadap ibu tetap diberikan secara maksimal. Keahlian dalam menangani psikiatri atau psikologi dan perkembangan anak juga diperlukan perawat karena menyadari kebutuhan informasi dan berbagai reaksi yang disorot dalam penelitian ini. 
Jurnal Care Vol .5, No2,Tahun 2017

\section{REFERENSI}

Cheng, X, Li, Z, Sun, X, Jiang, B, \& Zhuang, Z. (2016). Knowledge and willingness of breast cancer patients from Shanghai for genetic counseling and gene testing. Zhonghua yi xue yi chuan xue za zhi $=$ Zhonghua yixue yichuanxue zazhi $=$ Chinese journal of medical genetics, 33(5), 589.

Hendriani, Wiwin, Handariyati, Ratih, \& Sakti, Tirta Malia. (2006). Penerimaan keluarga terhadap individu yang mengalami keterbelakangan mental. INSAN Vol. 8 No. 2, Agustus.

Infodatin. (2015). Situasi Penyakit Kanker. Jakarta: Retrieved from https://www.google.co.id/url?sa $=\mathrm{t}$ $\underline{\text { \&rct }}=\mathrm{j} \& \mathrm{q}=\& \mathrm{esrc}=\mathrm{s} \&$ source $=$ web $\underline{\operatorname{cd}}=1 \& \mathrm{cad}=$ rja\&uact $=8 \& v e d=0 \mathrm{a}$ hUKEwjGv8PmpsjRAhXFsY8KH bgvBjUQFggcMAA\&url=http $\% 3 \mathrm{~A}$ $\% 2 \mathrm{~F} \% 2 \mathrm{Fwww}$.depkes.go.id $\% 2 \mathrm{Fres}$ ources $\% 2$ Fdownload $\% 2$ Fpusdatin \%2Finfodatin $\% 2$ Finfodatinkanker.pdf\&usg=AFQjCNE7wbfn TAZFliNmwGY-

ktAQjsVoTw\&sig2=HQm7N2vlk MC2fd0a9aJ1xA.

Klassen, Anne F, Raina, Parminder, McIntosh, Cameron, Sung, Lillian, Klaassen, Robert J, O'Donnell,
Maureen, . . . Dix, David. (2011). Parents of children with cancer: Which factors explain differences in health-related quality of life. International Journal of Cancer, 129(5), 1190-1198.

Kübler-Ross, Elisabeth, \& Kessler, David. (2014). On grief and grieving: Finding the meaning of grief through the five stages of loss: Simon and Schuster. Marshall, C.A. (2010). Surviving Cancer as a Family and Helping Co-Survivors Thrive: Praeger/ABC-CLIO.

Reed, Rebecca G, Weihs, Karen L, Sbarra, David A, Breen, Elizabeth C, Irwin, Michael R, \& Butler, Emily A. (2016). Emotional acceptance, inflammation, and sickness symptoms across the first two years following breast cancer diagnosis. Brain, behavior, and immunity, 56, 165174.

Rydlo, Cecilia. (2010). Fighting for the otherness: student nurses' lived experiences of growing in caring.

Saragih, Rosita. (2012). Peranan Dukungan Keluarga dan Koping Pasien dengan Penyakit Kanker terhadap Pengobatan Kemoterapi di RB 1 Rumah Sakit Umum Pusat Haji Adam Malik Medan Tahun 
Jurnal Care Vol .5, No2,Tahun 2017

2010. Jurnal Keperawatan. FIK, UDA, Medan.

Siburian, Christine Handayani, \& Wahyuni, Sri Eka. (2012).

Dukungan Keluarga dan Harga

Diri Pasien Kanker Payudara di RSUP H. Adam Malik Medan. E- jurnal Keperawatan Klinis Universitas Semarang, 2(1).

Telford, Kerry, Kralik, Debbie, \& Koch, Tina. (2006). Acceptance and denial: implications for people adapting to chronic illness: literature review. Journal of advanced nursing, 55(4), 457-464. 